\title{
Factors Affecting Financial Distress in Manufacturing Companies in the Food and Beverage Sub-Sector Listed on the Indonesia Stock Exchange in 2016-2020
}

\author{
Tina Novianti Sitanggang ${ }^{1}, \mathrm{Cindy}^{2}, \mathrm{Hansen}^{3}, \mathrm{Jesslyn}^{4}, \mathrm{Cynthia}^{5}$ \\ 1,2,3,4,5 Universitas Prima Indonesia, Indonesia \\ tinapaulus7371@gmail.com
}

\begin{abstract}
This study was conducted to determine the factors affecting financial distress in Manufacturing Companies in the Food and Beverage Sub-Sector Listed on the Indonesia Stock Exchange in 2016-2020. The data used is sourced from the company's financial statements on the Indonesia Stock Exchange, and the sample has been selected based on predetermined criteria. The population in this study are all Manufacturing Companies in the Food and Beverage Sub-Sector Listed on the Indonesia Stock Exchange in 2016-2020 totaling 30 companies, with purposive sampling method, the sample received is 12 companies. From this research, it can be seen that sales growth and working capital turnover partially effect financial distress significantly. Institutional ownership and debt to equity ratio have an insignificant effect on financial distress. All variables have a significant effect on financial distress simultaneously.
\end{abstract}

Keywords

sales growth; institutional ownership; debt to equity ratio; working capital turnover; financial distress

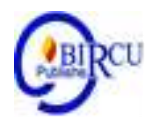

\section{Introduction}

Covid-19 or Corona Virus Disease 2019 is a disease outbreak that is thought to have spread since August 2019 in China and spread to 18 countries as of January 30, 2020, killing so many people, and on January 30, 2020, WHO also declared a global emergency against this virus outbreak (https://www.kompas.com/sains/read/2020/06/10/100300023/virus-corona-didugamenyebar-di-china-sejak-agustus-2019-ini-buktinya). Covid-19 is not only causing problems in the health sector but also problems in the economy, as well as what is felt by Indonesia, which is experiencing a weakening of the economic sector which is exacerbated by the lockdown which causes many layoffs and increases the number of unemployed.

The three major impacts of the pandemic on the Indonesian economy, namely household consumption or purchasing power, which supports 60 percent of the economy, fell quite deep. This is evidenced by data from BPS which recorded that household consumption fell from 5.02 percent in the first quarter of 2019 to 2.84 percent in the first quarter of this year, the second impact is the existence of prolonged uncertainty so that investment also weakens and has implications for the cessation of business. and the third impact is that the entire world is experiencing a weakening economy, causing commodity prices to fall and Indonesia's exports to several countries also stalling (https://republika.co.id/berita/qdgt5p383/tiga-dampak-besar-pandemi-covid19-bagiekonomi-ri).

The Minister of National Development Planning/Head of Bappenas, Suharso Monoarfa, predicts that the country's economic growth in the second quarter of 2020 will continue to decline. As an example, he gave the example of 10 million workers in the 
manufacturing sector who have lost half their working hours since mid-March this year, a manufacturing worker worked 40 hours per week, then multiplied by 1,000. He estimates that the corona pandemic outbreak has been running for about 12 weeks from mid-March to early June, so the figure is 480 thousand hours. "It's easy for us to take 400 thousand hours in 10 weeks. Times 10 million (manufacturing workers), meaning 4 billion work hours. This is 4 billion lost work hours," he explained. it means how much is lost? Approximately Rp 80 trillion. Divided in half because it is half, so Rp 40 trillion. So Rp 40 trillion is lost," he said (https://www.liputan6.com/bisnis/read/4274514/industrimanufaktur-kehilangan-pendapatan-rp-40-triliun-imbas-corona).

One of the industries most affected by COVID-19 is the food and beverage industry, with sales experiencing a drastic decline in sales as a result of the blocked distribution sector, where many shops, retails and markets were closed, resulting in distribution closures. from the factory (https://economy.okezone.com/read/2020/06/03/320/2223930/industri-mamin-anjlokpengusaha-jaga-mata-rantai-pasokan-di-market-place).

Whereas previously manufacturing companies in the processing industry showed very good export performance with an increase of 10.93 percent from the same period last year. Suryanto (2020) said that the export value of the processing industry in February 2020 was recorded at US $\$ 11.03$ billion, an increase of 2.73 percent compared to January 2020 which reached US $\$ 10.73$ billion. Where the food and beverage sector, which became the largest foreign exchange earner of the total export value of the processing industry at the beginning of this year, amounted to US $\$ 4.7$ billion. Janu Suryanto also stated that this is an important point for the government to pay special attention to the development of the manufacturing industry sector.

Therefore, the food and beverage sector industry is a good export sector and provides benefits in the form of a source of state foreign exchange reserves, which can also improve the country's economy, suppress inflation, and assist the development of SMEs. So we need to avoid a reduction in income in this sector by minimizing the possibility of bankruptcy that may occur due to the current economic conditions, which we can examine through the financial statements. By looking at sales growth and whether the strategy used is appropriate, which can be measured by sales growth, it is also necessary to pay attention to non-financial ratios such as institutional ownership in order to know the proportion of company shares owned by institutions. In addition, leverage ratios such as the debt to equity ratio also need to be considered in order to know the company's ability to meet its obligations when it will experience liquidity. Likewise, the activity ratio in the form of working capital turn over to find out the amount of sales that can be obtained for each rupiah of working capital.

\section{Review of Literature}

\subsection{Effect of Sales Growth on Financial Distress}

According to research conducted by Hidayat (2020) states that sales growth affects the possibility of financial distress. Where the higher the sales growth ratio indicates that the company has succeeded in carrying out its strategies and activities, the higher the profit generated. A company with increased sales growth has a tendency to be able to maintain its business continuity and reduce the possibility of financial distress. Conversely, if sales growth declines, the company's performance will get worse so that this can increase the potential for financial distress. 
Increasingly, employers, trade unions, health and safety representatives at work are finding guidance on the nature and causes of the stress problem and on the public sector requirements relating to its prevention and control. A number of factors have to be considered in the study of stress, for example, the multidimensionality of the nature of work place stress, definition of stress, the direct relationship between stress and behaviour, coping with stress and the increasing negative effect of stress on work productivity (Orji, 2020).

\subsection{Effect of Institutional Ownership on Financial Distress}

According to Pamungkas (2019), institutional ownership has no effect on the prediction of financial distress. According to research conducted by Hidayat (2020) states that institutional ownership has no effect on financial distress. Meanwhile, research from Pandegirot et al (2019) said that institutional ownership had a simultaneous effect on financial distress.

\subsection{Effect of Debt to Equity Ratio on Financial Distress}

Emingnungtyas (2017) in his research says that leverage as measured by the debt to equity ratio has no effect on financial distress. However, Fardania et al (2019), the results of their research state that there is an influence of the debt to equity ratio (DER) on financial distress. This means that if DER complies, it will reduce financial distress and vice versa if DER increases it will increase financial distress.

\subsection{Effect of Working Capital Turnover on Financial Distress}

According to research from Nugraha and Fajar (2018), it states that working capital turnover has no significant effect on financial distress. Meanwhile, research from Lestari and Ardiana (2019) says that working capital turnover partially has a positive effect on financial distress, where when the working capital turnover value increases, the modified zscore value that calculates financial distress also increases where this increase leads to normal or healthy conditions and so the other way around.

\section{Research Methods}

This research uses quantitative research methods. The quantitative data used is secondary data in the form of financial reports published on the Indonesia Stock Exchange. Sources of data obtained by documentation studies. The population of this research are all manufacturing companies in the food and beverage sub-sector listed on the Indonesia Stock Exchange from 2016 to 2020, totaling 30 companies. According to Sugiyono (2017:81), the sample is part of the number and characteristics possessed by the population. The sampling technique in this study was based on purposive sampling, with the purposive sampling method, the samples received were 12 companies. The data analysis technique in this research is descriptive statistical analysis, multiple regression analysis such as partial test ( $\mathrm{t}$ test), simultaneous test ( $\mathrm{F}$ statistic test), and coefficient of determination. 


\section{Results and Discussion}

\subsection{Descriptive Statistics}

Table 1. Descriptive Statistics Results

\begin{tabular}{|l|r|r|r|r|r|}
\hline & $\mathrm{N}$ & \multicolumn{1}{|c|}{ Minimum } & Maximum & \multicolumn{1}{c|}{ Mean } & Std. Deviation \\
\hline X $_{1}$ SSALES & 60 & -.70 & .50 & .0300 & .17399 \\
X $_{2}$ INST & 60 & .40 & 1.00 & .6333 & .16536 \\
X $_{3}$ DER & 60 & -2.10 & 5.40 & .8667 & 1.02091 \\
X $_{4}$ WCT & 60 & -14.90 & 165.60 & 6.0433 & 23.56352 \\
Y_FD & 60 & -13.40 & 16.10 & 4.5900 & 5.37170 \\
Valid N (listwise) & 60 & & & & \\
\hline
\end{tabular}

Source: Research Results

Based on the results of the descriptive statistics test above, the following explanation is obtained:

The variable $\mathrm{X}_{1 \_}$SALES with a sample size of 60 has a minimum value of -0.70 , namely at PT. Tiga Pilar Sejahtera Food Tbk in 2017 while the maximum value is PT. Prasidha Aneka Niaga Tbk in 2017 was 0.50 with an average of 0.0300 and a standard deviation of 0.17399 .

The $\mathrm{X}_{2}$ INST variable with a sample size of 60 has a minimum value of 0.40 , namely at PT. Ultrajaya Milk Industry \& Trading Company Tbk in 2016-2020 and at PT. Tiga Pilar Sejahtera Food Tbk in 2018-2019 and also at PT. Tri Banyan Tirta Tbk in 20172020 while the maximum value is in the company PT. Sekar Laut Tbk in 2016-2019 was 1.00 with an average of 0.6333 and a standard deviation of 0.16536 .

The variable $X_{3}$ DER with a sample size of 60 has a minimum value of -2.10 , namely at PT. Tiga Pilar Sejahtera Food Tbk in 2019 while the maximum value is PT. Prasidha Aneka Niaga Tbk in 2020 was 5.40 with an average of 0.8667 and a standard deviation of 1.02091 .

The variable $\mathrm{X}_{4}$ WCT with a sample size of 60 has a minimum value of -14.90 , namely at PT. Multi Bintang Indonesia Tbk in 2017 while the maximum value is in the company PT. Prasidha Aneka Niaga Tbk in 2018 was 165.60 with an average of 6.0433 and a standard deviation of 23.56352 .

The variable Y_FD with a sample size of 60 has a minimum value of -13.40 , namely at PT. Tiga Pilar Sejahtera Food Tbk in 2017 while the maximum value is PT. Multi Bintang Indonesia Tbk in 2017 was 16.10 with an average of 4.5900 and a standard deviation of 5.37170 . 
Table 2. $\mathrm{t}$ Test Results

Coefficients $^{\mathrm{a}}$

\begin{tabular}{|c|c|c|c|c|c|c|c|}
\hline \multirow[t]{2}{*}{ Model } & \multicolumn{2}{|c|}{$\begin{array}{l}\text { Unstandardized } \\
\text { Coefficients }\end{array}$} & $\begin{array}{c}\text { Standardized } \\
\text { Coefficients }\end{array}$ & \multirow[t]{2}{*}{ t } & \multirow[t]{2}{*}{ Sig. } & \multicolumn{2}{|c|}{$\begin{array}{c}\text { Collinearity } \\
\text { Statistics }\end{array}$} \\
\hline & B & Std. Error & Beta & & & Tolerance & VIF \\
\hline (Constant) & 3.042 & 2.577 & & 1.181 & .243 & & \\
\hline $\mathrm{X}_{1 \_S A L E S}$ & 11.866 & 3.779 & .384 & 3.140 & .003 & .977 & 1.024 \\
\hline $1 \mathrm{X}_{2} \_\mathrm{INST}$ & 2.097 & 4.022 & .065 & .521 & .604 & .955 & 1.047 \\
\hline $\mathrm{X}_{3}$ DEER & .233 & .650 & .044 & .358 & .722 & .959 & 1.042 \\
\hline $\mathrm{X}_{4} \_\mathrm{WCT}$ & -.056 & .028 & -.245 & -2.010 & .049 & .983 & 1.018 \\
\hline
\end{tabular}

a. Dependent Variable: Y_FD

Source: Research Results

From the data above, the discussion with the table value of 1.67303 is obtained as follows:

1. Partially the variable $X_{1}$ SSALES with a $t_{\text {count }}$ of 3.140 with a significant value of 0.003 where $3.140>1.67303$ and $0.003<0.05$, which means that sales growth has a significant effect on financial distress.

2. Partially, the $X_{2}$ INST variable with a $t_{\text {count }}$ of 0.521 with a significant value of 0.604 , where $0.521<1.67303$ and $0.604>0.05$, which means that institutional ownership has no significant effect on financial distress.

3. Partially the $X_{3}$ DER variable with a $t_{\text {count }}$ of 0.358 with a significant value of 0.722 where $0.358<1.67303$ and $0.722>0.05$ which means that the debt to equity ratio has no significant effect on financial distress.

4. Partially, the $X_{4}$ WCT variable with a $t_{\text {count }}$ of -2.010 with a significant value of 0.049 where $2.010>1.67303$ and $0.049<0.05$, which means that working capital turnover has a significant effect on financial distress.

4.3 F Test

Table 3. F Test Results

ANOVA $^{\mathrm{a}}$

\begin{tabular}{|rl|r|r|r|r|r|}
\hline Model & & Sum of Squares & df & Mean Square & F & Sig. \\
\hline \multirow{4}{*}{1} & Regression & 331.923 & 4 & 82.981 & 3.330 & $.016^{\mathrm{b}}$ \\
& Residual & 1370.531 & 55 & 24.919 & & \\
& Total & 1702.454 & 59 & & & \\
\hline
\end{tabular}

a. Dependent Variable: Y_FD

b. Predictors: (Constant), $\mathrm{X}_{4} \_$WCT, $\mathrm{X}_{2}$ INST, $\mathrm{X}_{1} \_S A L E S, \mathrm{X}_{3} \_$DER

Source: Research Results

Based on the above test, the value of $\mathrm{F}_{\text {count }}$ is 3.330 with $\mathrm{F}_{\text {table }} 2.56$ and a significant value of 0.016 , where $3.330>2.56$ and $0.016<0.05$, then sales growth, institutional ownership, debt to equity ratio, and working capital turnover have a significant effect simultaneous against financial distress in the Food and Beverage Sub-Sector Listed on the Indonesia Stock Exchange in 2016-2020. 


\subsection{Coefficient of Determination Test}

Table 4. Coefficient of Determination Test Results Model Summary ${ }^{\mathrm{b}}$

\begin{tabular}{|l|r|r|r|r|r|}
\hline Model & \multicolumn{1}{|c|}{$\mathrm{R}$} & $\mathrm{R}$ Square & $\begin{array}{c}\text { Adjusted R } \\
\text { Square }\end{array}$ & $\begin{array}{c}\text { Std. Error of the } \\
\text { Estimate }\end{array}$ & Durbin-Watson \\
\hline 1 & $.442^{\mathrm{a}}$ & .195 & .136 & 4.99187 & 2.243 \\
\hline
\end{tabular}

a. Predictors: (Constant), $X_{4} \_W C T, X_{2}$ INST, $X_{1} \_S A L E S, X_{3}$ DER

b. Dependent Variable: Y_FD

Source: Research Results

Based on the data above, the R Square value is 0.195 or equal to $19.5 \%$ which means that sales growth, institutional ownership, debt to equity ratio and working capital turnover have effect on financial distress of $19.5 \%$ and the remaining $80.5 \%$ influenced by other variables not examined in this study.

\section{Conclusion}

From this research, it can be seen that sales growth and working capital turnover partially effect financial distress significantly. Institutional ownership and debt to equity ratio have an insignificant effect on financial distress. All variables have a significant effect on financial distress simultaneously. follows:

After concluding the results of this study, the following suggestions can be given as

1. For the next researcher, it is expected to consider adding more samples in order to produce more accurate results.

2. For the next researcher, it is expected to examine other variables such as debt to asset ratio, net profit margin, managerial ownership and other variables.

3. For the next researcher, it is hoped that they can examine other sub-sector companies.

\section{References}

Economy.okezone.com. (03 Juni 2020). Industri Mamin Anjlok, Pengusaha Jaga Mata Rantai Pasokan di Market Place. Accessed on 10 September 2020, from https://economy.okezone.com/read/2020/06/03/320/2223930/industri-mamin-anjlokpengusaha-jaga-mata-rantai-pasokan-di-market-place.

Eminingtyas, Reta. (2017). Pengaruh Ukuran Perusahaan, Likuiditas, Leverage, Sales Growth dan Operating Capacity terhadap Financial Distress pada Perusahaan Manufaktur (Terdaftar di BEI). Sekolah Tinggi Ilmu Ekonomi Perbanas.

Fardania, Intan Meri, Ermawati, Emmy \& Wiyono, Wimbo. (2019). Pengaruh Likuiditas, Solvabilitas, dan Profitabilitas terhadap Financial Distress (Studi Empiris pada Perusahaan Manufaktur Sub sektor Makanan dan Minuman yang Terdaftar di Bursa Efek Indonesia periode 2015-2017). Progress Conference, 2(7).

Hidayat, Khoiri. (2020). Pengaruh Financial Indicators dan Non-Financial Indicators Terhadap Kemungkinan Financial Distress (Studi Empiris pada Perusahaan Manufaktur yang Terdaftar di Bursa Efek Indonesia Tahun 2016-2018). Universitas Muhammadiyah Surakarta. 
Kompas.com. (10 Juni 2020). Virus Corona Diduga Menyebar di China sejak Agustus 2019, Ini buktinya. Accessed on 10 September 2020, from https://www.kompas.com/sains/read/2020/06/10/100300023/virus-corona-didugamenyebar-di-china-sejak-agustus-2019-ini-buktinya.

Lestari, Rahayu \& Ardiana, Meta. (2019). Pengaruh Working Capital Turnover dan Leverage terhadap Financial Distress (Study Empiris pada Perusahaan Jasa Subsektor Property, Rela Estate dan Konstruksi Bangunan yang tercatat di Bursa Efek Indonesia). Journal of Finance and Accounting Studies, 1(2).

Liputan6.com. (09 Juni 2020). Rp 40 Triliun Imbas Corona. Accessed on 10 September 2020, from https://www.liputan6.com/bisnis/read/4274514/industri-manufakturkehilangan-pendapatan-rp-40-triliun-imbas-corona.

Nugraha, Akhbar \& Fajar, Catur Martian. (2018). Financial Distress pada PT Panasia Indo Resources Tbk. Jurnal Isnpirasi Bisnis dan Manajemen, 2(1), 29-42.

Orji, M.G., and Yakubu, G.N. (2020). Effective Stress Management and Employee Productivity in the Nigerian Public Institutions; A Study of National Galary of Arts, Abuja, Nigeria. Budapest International Research and Critics Institute-Journal (BIRCI-Journal). P. 1303-1315.

Pamungkas, Risang. (2019). Pengaruh Likuiditas, Profitabilitas, Sales Growth, dan Struktur Kepemilikan Terhadap Financial Distress (Studi pada Perusahaan Pertambangan yang Terdaftar di Bursa Efek Indonesia Periode 2014-2017). Institut Agama Islam Negeri Surakarta.

Pandegirot, Sonia Ch. G., Rate, Paulina Van, \& Tulung, Joy E. (2019). Analisis Pengaruh Current Ratio, Institutional Ownership, Debt to Asset Ratio Terhadap Kondisi Financial Distress pada Perusahaan Property dan Real Estate Di Bursa Efek Indonesia 2013-2017. Universitas Sam Ratulangi Manado.

Republika.co.id. (15 Juli 2020). Tiga Dampak Besar Pandemi Covid-19 Bagi Ekonomi RI. Accessed on 10 September 2020, from https://republika.co.id/berita/qdgt5p383/tigadampak-besar-pandemi-covid19-bagi-ekonomi-ri.

Sugiyono. (2017). Metode Penelitian Kuantitatif, Kualitatif, dan R\&D. Bandung: CV Alfabeta.

Suryanto. (2015). Pengantar Ilmu Komunikasi Bandung: CV Pustaka Setia. 